\title{
Sturm und Drang and Mental Health During Adolescence
}

\author{
Hana Song \\ 질풍노도와 청소년기 정신건강 \\ 송하나 \\ 성균관대학교 아동청소년학과
}

Department of Child Psychology and Education, Sungkyunkwan University, Seoul, Korea

정신건강은 청소년기 발달의 중요한 이슈이다. 학부모들은 교사 및 연구자들과의 인터뷰에서, 어릴 때는 착한 아이였던 자녀가 사춘기가 되면서 말을 듣지 않는 나쁜 아이가 되었다 고 종종 호소한다. 이처럼 사춘기 청소년들이 보이는 반항적 인 정서와 불안정한 행동 경향을 질풍노도(Sturm und Drang) 라고 부른다.

최근의 뇌 발달 연구들은 질풍노도 현상을 지지하는 결 과를 제시하고 있다. 이 시기에는 이성적인 판단이나 인지 적 통제를 주관하는 신경 기제가 아직 충분히 발달하지 않 아서 제 기능을 다하지 못하기 때문에(Casey et al., 2010; Sercombe, 2014), 충동적이고 거부적인 문제 행동을 자연스 러운 발달적 과정으로 볼 수 있다. 특히, 현대의 청소년들은 부모들보다 새로운 디지털 환경에 더 잘 적응할 수 있는 기 술과 능력을 가지고 있다. 이러한 상황에서 청소년을 주변인 (marginal man)으로만 생각하는 기성세대의 가치와 관습은 쉽게 받아들여지기 어렵기 때문에, 청소년들이 더욱 공격적 이고 반항적인 것으로 오인될 수 있다.

그러나 청소년의 문제 행동이 시간이 지나면 자연스럽게 줄어들거나 없어지는 사춘기 성장통 만은 아니라는 점을 생 각해야 한다. 무엇보다, 반항, 충동, 불안정, 말썽, 혼란, 일탈 등으로 표현되는 질풍노도를 모든 청소년들이 겪는 것은 아 니다. 또한 전통적인 집단주의 문화의 청소년들이 산업화된

Corresponding Author: Hana Song, Editor-in-Chief Department of Child Psychology and Education, Sungkyunkwan University, 25-2, Sungkyunkwan-Ro, Jongno-Gu, Seoul 03063, Korea

E-mail: jni4ever@skku.edu
서구의 청소년들보다 사춘기 동안 정서적, 행동적 문제를 덜 경험한다는 점에서, 질풍노도가 생물학적인 것인지, 사회문 화적인 것인지에 대한 학술적 논쟁이 이어지고 있다(Arnett, 1999; Côté, 1994).

특히, 부정적인 가족 관계는 청소년기 문제 행동의 중요 한 위험 요인으로 꼽힌다. 부모의 심리적 통제가 높을수록 청소년들은 문제 행동을 더 많이 나타내는 경향이 있었다 (Gray \& Steinberg, 1999). 그러나 많은 청소년들이 사춘기에 도 부모와 여전히 좋은 관계를 유지하고 또래들과 적극적으 로 상호작용 하면서, 다양한 경험을 통해 긍정적 자아상을 형성한다. 또한 어릴 때는 몰랐던 새로운 자신의 적성을 발 견하기도 한다. 따라서, 자연스러운 질풍노도 현상처럼 보이 는 청소년기 문제 행동은 자연스러운 것이 아니라 까다로운 기질, 역기능적 가족 관계, 낮은 인지 능력과 학업 성취, 또래 와의 갈등, 건강 문제, 외상적인 개인 경험, 사회 부적응 등 정신 건강을 저해하는 위험 요인에 영향을 받은 결과일 수 있다.

한편, 질풍노도 현상은 일시적인 것이 아니라 장기적인 발달적 궤도를 통해 나타난 정신 병리적 문제 행동일 수 있 다. 이러한 문제들은 영·유아기에는 뚜렷이 관찰되지 않다 가 중기 아동기나 청소년기가 되어서야 인식되는 경우가 많 다. 예를 들어, 학교 부적응과 심각한 외현적 문제 행동을 보

(C)The Korean Association of Child Studies

This is an Open Access article distributed under the terms of the Creative Commons Attribution Non-Commercial License (http:// creativecommons.org/licenses/by-nc/4.0) which permits unrestricted noncommercial use, distribution, and reproduction in any medium, provided the original work is properly cited. 
이는 아동들 중의 일부는 반항 장애나 품행 장애로 진단된다 (Herbert, 2005). 이러한 아동들은 영·유아기에 짜증을 잘 내 는 기질, 수면, 섭식, 배변 문제를 보이지만, 이러한 징후들이 진단 준거에는 맞지 않기 때문에 학령기 전후가 되어야 문 제로 가시화되는 경향이 있다(Caron \& Rutter 1991). 이처럼 청소년의 문제 행동이 장기적인 경로를 가지는 경우에는 사 춘기 반항 정도로 다루어서는 안 되며 체계적이고 적극적인 중재가 필요하다.

아동학회지 이번호에는 청소년기 우울, 비행, 자살생각, 휴대전화사용, 자존감, 행복감 및 삶의 만족도와 이에 영향 을 미치는 부모-자녀 및 또래 관계, 다양한 중재 방안을 다룬 연구들이 소개되고 있다. 이와 같은 주제들을 보다 포괄적이 고 장기적인 발달적 관점에서 바라보는 것이 청소년들의 정 서적 어려움과 행동 문제를 이해하는데 도움이 될 것이다.

Mental health is an important issue in adolescent development. Parents interviewed educators and researchers, often claiming that children who were good in early childhood became naughty and tough in puberty. This adverse emotionality and unstable behavioral tendency in adolescence has been called as Sturm und Drang.

This stormy tendency is supported by recent studies on brain development. Because the neurological mechanisms that underlie rational judgment or cognitive control are not fully functional at this age (Casey et al., 2010; Sercombe, 2014), such impulsivity and adversity can be seen as natural developmental phenomena rather than as pathological problems. In particular, adolescents in contemporary society have more advanced levels of digital skills and technical competence (as required for future society) than their parents. As such, the values and customs of the older generation, who tend to think of adolescents as the marginal man, are more likely to be rejected by adolescents.

However, it is important to note that the problematic behaviors of stormy adolescents do not naturally decrease or disappear over time. Above all, it is not the rule that all teenagers go through the Strum und Drang period, which manifests as rebellion, impulsivity, instability, trouble, turmoil, and aberration. Because the adolescents of traditional collectivist culture experience less emotional and behavior problems than those in industrialized Western culture, there is still an academic debate about whether Strum und Drang is biologically or socioculturally determined (Arnett, 1999; Côté, 1994).

In particular, a negative family relationship is an important risk factor for adolescents' behavior problems. It has been reported that the higher the parental psychological control was, the more the adolescent problem behaviors appeared (Gray \& Steinberg, 1999). However, many adolescents do not experience emotional disturbances and psychological difficulties during puberty. Adolescents can maintain good relationship with their parents and peers, and form positive concepts of self-image during this period through various experiences. They can also discover a new aptitude that they did not have when they were young. Thus, considerable levels of problem behaviors during the Sturm und Drang period can be caused by various risk factors such as a difficult temperament, an adverse family relationship, a lack of cognitive ability, low academic achievement, conflict with peers, health problems, traumatic personal experiences, and social maladjustment.

In addition, Sturm und Drang might not be a temporary phenomenon but a problematic behavior that has emerged through long-term developmental trajectories. Psychopathological problems are not observed clearly in infancy and early childhood but are often recognized and diagnosed during middle childhood and adolescence. For example, some children with school maladjustment and intense externalizing behavioral problems are diagnosed with oppositional defiant disorder or conduct disorder (Herbert, 2005). Such children exhibit an irritable temperament and sleeping and eating problems during infancy and early childhood, but these symptoms do not meet the diagnostic criteria. Thus, pathological problems are more likely to be diagnosed just before and after school age (Caron, \& Rutter, 1991). Such long-term pathways of behavior problems among 
adolescents require systematic and active intervention.

This issue of the Korean Journal of Child Studies introduces research on adolescents' depression, delinquency, suicidal ideation, cellphone use, selfesteem, happiness and life satisfaction, parent-adolescent relationships, peer interactions, and various intervention approaches for adolescents. Considering these issues with a more comprehensive lifespan perspective will help researchers, practitioners, and students understand adolescents' emotional difficulties and behavior problems.

Hana Song, Editor-in-Chief of the Korean Journal of Child Studies.
Herbert, M. (2005). Developmental Problems of Childhood and Adolescence: Prevention, Treatment and Training. Malden, MA: Blackwell Publishing. doi:10.1002/9780470773888

Sercombe, H. (2014). Risk, adaptation and the functional teenage brain. Brain and Cognition, 89, 61-69. doi:10.1016/ j.bandc.2014.01.001

\section{ORCID}

Hana Song http://orcid.org/0000-0002-7745-7303

\section{Conflict of Interest}

No potential conflict of interest relevant to this editorial was reported.

\section{References}

\section{In English}

Arnett, J. J. (1999). Adolescent storm and stress, reconsidered. American Psychologist, 54(5), 317-326. doi:10.1037//0003066X.54.5.317

Caron, C., \& Rutter, M. (1991). Comorbidity in child psychopathology: Concepts, issues and research strategies. Journal of Child Psychology and Psychiatry, 32(7), 1063-1080. doi:10.1111/j.1469-7610.1991.tb00350.x

Casey, B. J., Jones, R. M., Levita, L., Libby, V., Pattwell, S. S., Ruberry, E. J., . . Somerville, L. H. (2010). The storm and stress of adolescence: Insights from human imaging and mouse genetics. Developmental Psychobiology, 52(3), 225-235. doi:10.1002/dev.20447

Côté, J. E. (1994). Adolescent storm and stress: An evaluation of the Mead-Freeman controversy. Hillsdale, NJ: Lawrence and Erlbaum Associate.

Gray, M. R., \& Steinberg, L. (1999). Unpacking authoritative parenting: Reassessing a multidimensional construct. Journal of Marriage and the Family, 61(3), 574-587. doi:10.2307/353561 